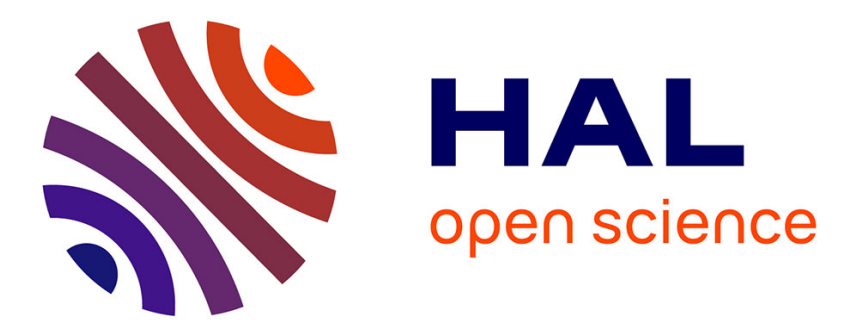

\title{
Palladium-Catalyzed Addition of 1,3-Diones to Ynamides: An Entry to Alkoxy-Substituted Enamides
}

Lionel V. Graux, Hervé Clavier, Gérard Buono

\section{To cite this version:}

Lionel V. Graux, Hervé Clavier, Gérard Buono. Palladium-Catalyzed Addition of 1,3-Diones to Ynamides: An Entry to Alkoxy-Substituted Enamides. ChemCatChem, 2014, 6 (9), pp.2544 - 2548. 10.1002/cctc.201402398 . hal-01409701

\section{HAL Id: hal-01409701 https://hal.science/hal-01409701}

Submitted on 7 Dec 2016

HAL is a multi-disciplinary open access archive for the deposit and dissemination of scientific research documents, whether they are published or not. The documents may come from teaching and research institutions in France or abroad, or from public or private research centers.
L'archive ouverte pluridisciplinaire HAL, est destinée au dépôt et à la diffusion de documents scientifiques de niveau recherche, publiés ou non, émanant des établissements d'enseignement et de recherche français ou étrangers, des laboratoires publics ou privés.

\section{(ㅇ)(1) $\$$}

Distributed under a Creative Commons Attribution - NonCommercial - NoDerivatives 44.0 
DOI: ((will be completed by the editorial staff))

\title{
Palladium-catalyzed addition of 1,3-diones to ynamides: an entry to unprecedentedalkoxy-substituted enamides
}

\author{
Lionel V. Graux, ${ }^{[\mathrm{a}]}$ Hervé Clavier, ${ }^{\text {[a] }}$ and Gérard Buono ${ }^{[\mathrm{a}]}$
}

A new metal-catalyzed addition reaction of 1,3-diketones to ynamides providing an access to unprecedented alkoxy-substituted enamides is disclosed herein. A screening of catalytic systems showed that either a phosphapalladacycle or a cationic gold complex were efficient to promote rapidly and cleanly this reaction. The scope investigation revealed that variously substituted terminal ynamides and cyclic 1,3-diones were well tolerated. The use of internal ynamides led to the formation of both $E$ - and Z-isomers with low to good selectivities. The mechanism proposal suggests that the phosphapallacycle acts as a $\pi$-Lewis acid to activate the ynamide.

Alkynes and more particularly the subgroup of nitrogensubstituted alkynes, ynamides, are important and versatile building blocks used in a myriad of chemical transformations. ${ }^{[1]}$ The electron-donating character of the nitrogen atom leads to a strong polarization of the triple bond, which alters perceptibly their reactivity compared to alkyl- or aryl-substituted alkynes. The keteniminium tautomeric form of ynamides shows clearly the regioselectivity of additions onto ynamides: nucleophiles

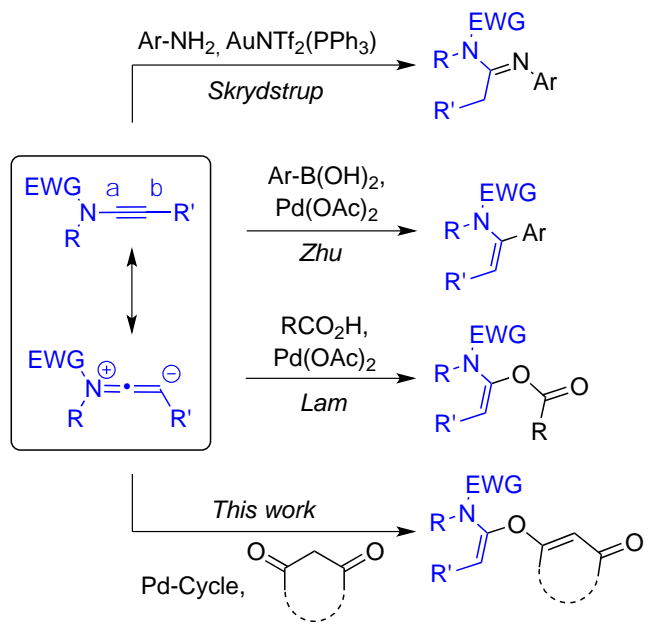

Scheme 1.Metal-catalyzed addition of $\mathrm{N}$, , C- and O-nucleophiles to ynamides.

[a] L. V. Graux, Dr. H. Clavier, Prof. Dr. G. Buono Aix Marseille Université, Centrale Marseille, CNRS, iSm2 UMR 7313, 13397, Marseille, France

E-mail: herve.clavier@univ-amu.fr

Supporting information for this article is available on the WWW under http://dx.doi.org/ are added at the $\alpha$-position to the nitrogen atom and the $\beta$ position reacts with electrophiles (Scheme 1). ${ }^{[2,3]}$ Since it gives a straightforward access to synthetically relevant functionalized enamides, additions of nitrogen-, carbon- or oxygen-containing nucleophiles at the position $\alpha$ have been investigated using various catalytic systems. ${ }^{[4]}$ For instance, Skrydstrud reported the gold-catalyzed addition of anilines to ynamides ${ }^{[5]}$ using the cationic complex AuNTf $\left(\mathrm{PPh}_{3}\right)$ developped by Gagosz. ${ }^{[6]}$ This catalyst was later used for ynamide dimerization giving rise to cyclopentadienes. ${ }^{[7]}$ On the other hand, palladium(II) acetate was found to promote efficiently the addition of boronic acids, as disclosed by $\mathrm{Zhu},{ }^{[8]}$ and the hydroacyloxylation of ynamides reported by Lam a couple of years ago. ${ }^{[9]}$

During the course of our researches on the [2+1] cycloaddition between alkynes and norbornene derivatives using palladium-basedcomplexes prepared from secondary phosphine oxide preligands, ${ }^{[10]}$ we noticed that the HerrmannBeller phosphapalladacycle H-B promoted this transformation in the case of polarized carbon-carbon triple bonds such as ynamides (Scheme 2). ${ }^{[11,12]}$ However, during the scope investigation, we observed that norbornene derivative $\mathbf{2 a}$ containing a 1,3-cyclopentanedione moiety did not afforded the expected [2+1] cycloadduct 3but nearly quantitative yield of 4aa resulting from the addition of the enol form of 2ato ynamide 1a (Scheme 2). Considering the fact that it gives an access to unprecedented alkoxy-substituted enamides, we decided to pursue the examination of this hitherto unknownreactivity. ${ }^{[13-15]}$

We started to investigate this original transformation by a thorough examination of the catalytic system using benchmark substrates: ynesulfonamide $\mathbf{1 a}$ and dimedone $\mathbf{2 b}$ (Table 1). Surprisingly, the $\alpha$-addition of 1,3-dione to ynamide occurs at room temperature without catalyst.However, after 4 days only $34 \%$ of $4 \mathrm{ab}$ was isolated along with a large amount of degradation products which complicated the purification step

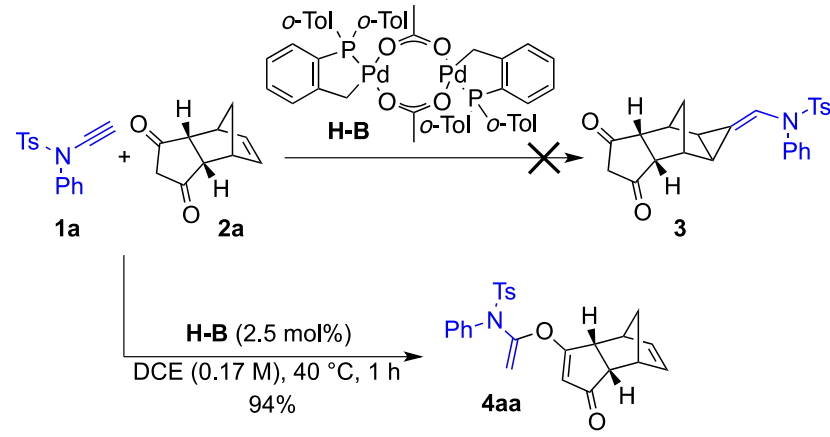

Scheme 2. Attempted Pd-catalyzed [2+1] cycloaddition of a 1,3-dionecontaining norbornene with an ynamide. 
(entry 1). Of note, heating the reaction mixture led to theincrease of the degradation rate. Herrman-Beller phosphapalladacycle $\mathbf{H}-\mathbf{B}$ was found competent to catalyserapidly and cleanly the addition of $\mathbf{2 b}$ to $\mathbf{1 a}$ (entry 2). The structure of $\mathbf{4 a b}$ was unambiguously determined by $X$ ray crystallography (Figure 1). ${ }^{[16]}$ The $C(9)=C(10)$ bond distance of 1.305(3) Åis significantly short for C-C double bond, especially for enamides(typically bond lengths between 1.35 and $1.39 \AA) .{ }^{[17]}$ Such a bond length is generally observed for $\mathrm{C}=\mathrm{C}$ in allenes. The bond angle $\mathrm{O}(2)-\mathrm{C}(9)-\mathrm{N}(1)$ of $110.3(2)^{\circ}$ is smaller than expected $\left(120^{\circ}\right)$. Dihedral angles $\mathrm{C}(1)-\mathrm{O}(2)-\mathrm{C}(9)$ $\mathrm{C}(10)$ and $\mathrm{C}(1)-\mathrm{O}(2)-\mathrm{C}(9)-\mathrm{N}(1)$, respectively $109.1(3)^{\circ}$ and $74.6(2)^{\circ}$ indicate a relatively weak steric congestion around the carbon-carbon double bond. More importantly, adduct 4abwas found quite stable in solution and could be easily purified by flash chromatography on silica gel. However, the newly formed $\mathrm{C}-\mathrm{O}$ bond was found sensitive to acidic tracesand its cleavage releasedthe dimedone $\mathbf{2} \mathbf{b}$ and $\mathrm{N}$-phenyl tosylamide. Therefore, chloroform- $d_{3}$ was filtrated on basic alumina prior to use in order to slow down the hydrolysis process. Control experiences carried with $\mathrm{PPh}_{3}, \mathrm{Pd}(\mathrm{OAc})_{2}$ and a mixture $\mathrm{Pd}(\mathrm{OAc})_{2} / \mathrm{PPh}_{3}(1: 2)$ showed a low formation of adduct $\mathbf{4 a b}$ in addition to noticeable amounts of degradation products (entries 3-5). Interestingly, gold-complex AuNTf $\left(\mathrm{PPh}_{3}\right)$ exhibited an analogous activity to the one observed with $\mathbf{H}-\mathbf{B}$ (entry 6 ). In order to probe that the Lewis acid character of gold is responsible for the catalysis, the

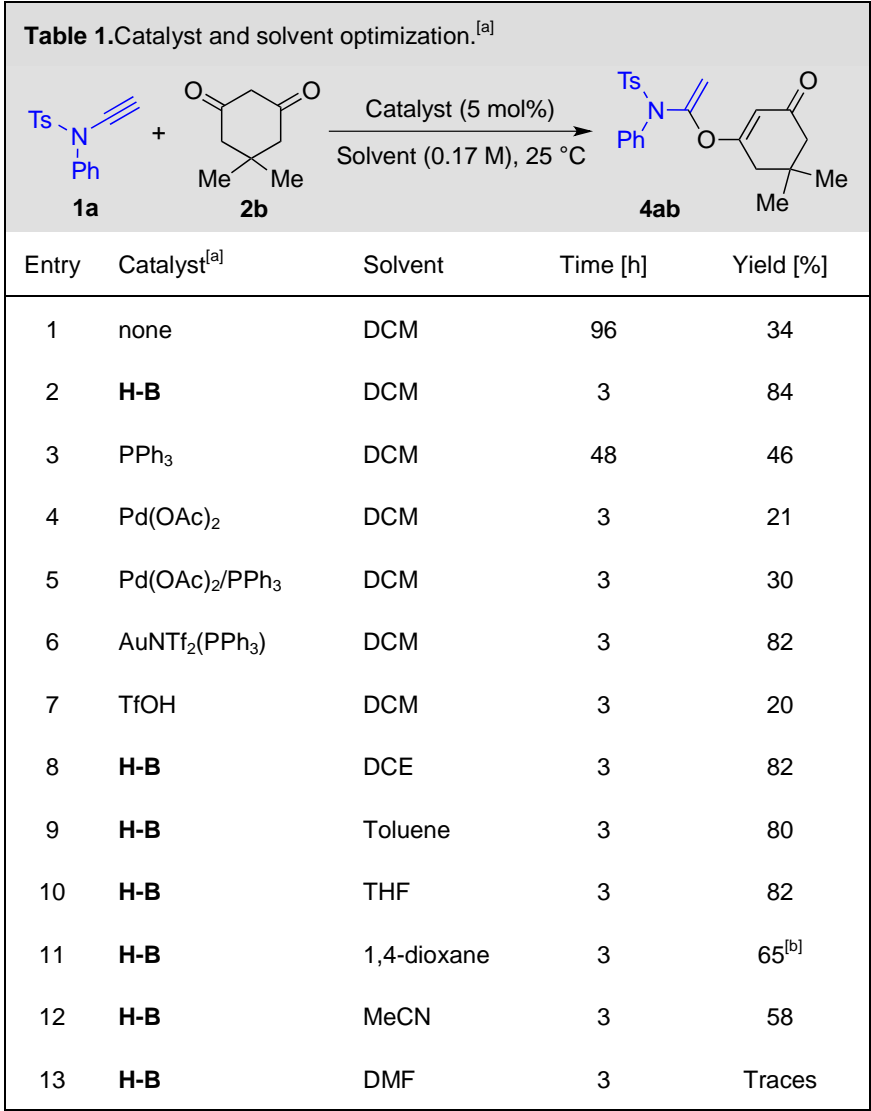

[a] Reaction conditions: $\mathbf{1 a}(0.5 \mathrm{mmol})$, dimedone2a ( $0.5 \mathrm{mmol}), 5 \mathrm{~mol} \%$ of catalyst $(2.5 \mathrm{~mol} \%$ of dimeric H-B), Solvent( $3 \mathrm{~mL})$. [b] $11 \mathrm{~mol} \%$ of 5 abwere also isolated. $\mathrm{Tf}=$ trifluoromethanesulfonyl $\left(\mathrm{CF}_{3} \mathrm{SO}_{2}\right)$

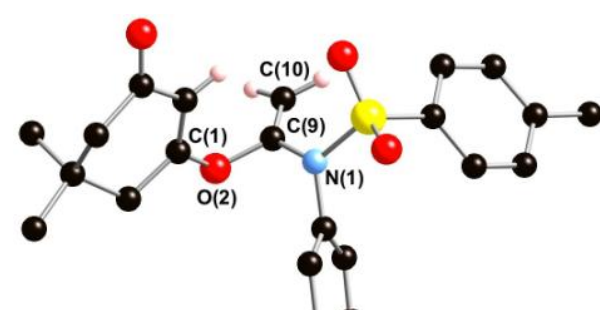

Figure 1.Ball-and-stick representation of adduct4ab (most of the hydrogens have been omitted for clarity)

reaction was performed in the presence of a strong Brønsted acid, triflic acid (entry 7).No improvement in comparison to the non-catalyzed addition of dimedone to ynamide 1awas noticed. Solvent screening revealed that, to the exception of DMF, various solvents were compatible with this palladium-mediated addition and 4ab was isolated in good yields (entries 2, 8-13). In dioxane, the reaction proceeded with the formation of byproduct $5 \mathbf{a b}$ in $11 \%$ yield in addition to $65 \%$ of $4 \mathbf{a b}$ (entry 11 ). With other solvents, only traces of $5 \mathrm{ab}$ were detected by ${ }^{1} \mathrm{H}$ NMR from the crude reaction mixture.

Having established the optimal reaction conditions, we further investigated the reaction scope with a range of 1,3diones or derivatives (Table 2). Cyclohexane-1,3-dione-based substrates $\mathbf{2 b} \mathbf{b}-\mathbf{2}$ e were found to be good nucleophiles and the corresponding alkoxy-substituted enamides 4ab-4ae were isolated in satisfactory yields in short reaction times(entries 25). The dissymmetric dione $\mathbf{2 d}$ gave rise to two isomers in ratio $4: 1$ in favour of 4 ad resulting from the attack of the more sterically demanding ketone (entry 4). 1,3-diketone 2 fwas tested but the lack of reactivity - even at higher temperature demonstrates that substitution in 2-position inhibits completely the addition (entry 5). Similarly to 6-membered 1,3-diones, 5membered analogues were smoothly added to ynamide $\mathbf{1 a}$ (entries 7-9). Despite a prolonged heating at $60{ }^{\circ} \mathrm{C}$, 1,3indandione $\mathbf{2 j}$ did not react (entry 10 ). On the other hand, other aromatic 1,3-diones such as 1,3-phenalendione $\mathbf{2 k}$ and 4hydroxycoumarine 2l led to the formation of the expected adduct in moderate yields, respectively 55 and $51 \%$ (entries 11 and 12). Finally, we were unable to carry out this transformation with acyclic 1,3-diones, for example $\mathbf{2 m}$ (entry 13). More than the keto-enol equilibrium, we believe that the acidity of the 1,3-diones allows for the rationalization of the success of the addition. Indeed, $\mathrm{p} K_{\mathrm{a}}$ values for cyclic 1,3diones, including 4-hydroxycoumarine 2I, are around 5 (dimedone $\mathbf{2 b}, \mathrm{p} K_{\mathrm{a}}=5.2$ ), whereas acyclic analogues show higher values $\left(2 \mathrm{~m}, \quad \mathrm{p} K_{\mathrm{a}}=9.2\right) .{ }^{[18]}$ Similarly 1,3-indandione $2 \mathbf{j}\left(\mathrm{p} K_{\mathrm{a}}=7.2\right)$ is significantly less acidic than other cyclic 1,3dioneswhich would explain the lack of reactivity observed for this substrate. In a general manner, all isolated compounds showed a good stability at solid state.

We then examined the transformation scope with respect to the ynamide partner (Table 3). In addition to the $\mathrm{N}$-substituted phenylynamide 1a, analogues 1b-1eafforded the corresponding adducts with good to excellent yields (entries 1 4). Other ynesulfonamides $\mathbf{1 f}$ and $\mathbf{1 g}$ were found to be good partners for the addition of dimedone $\mathbf{2 b}$ (entries 5 and 6 ). Ynamides bearing different electron-withdrawinggroups such 


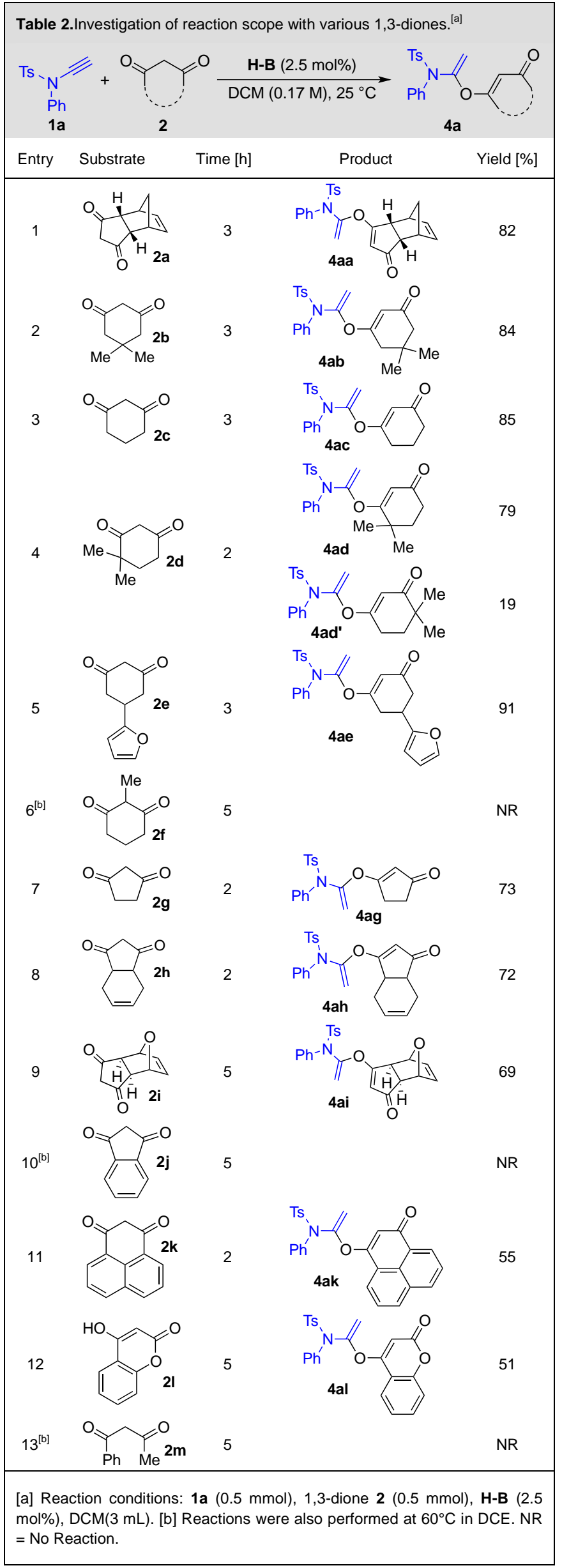

as carbamate or amide were also found to be reactive in this transformation (entries 7 and8). Only the vinylogous indolecontaining ynamide $\mathbf{1 j}$ gave the isolated product with a moderate yield $(43 \%$, entry 9$)$.

Next, a series of internal benzylynamides 6was studiedand it appeared that a thermal activation at $80^{\circ} \mathrm{C}$ was required

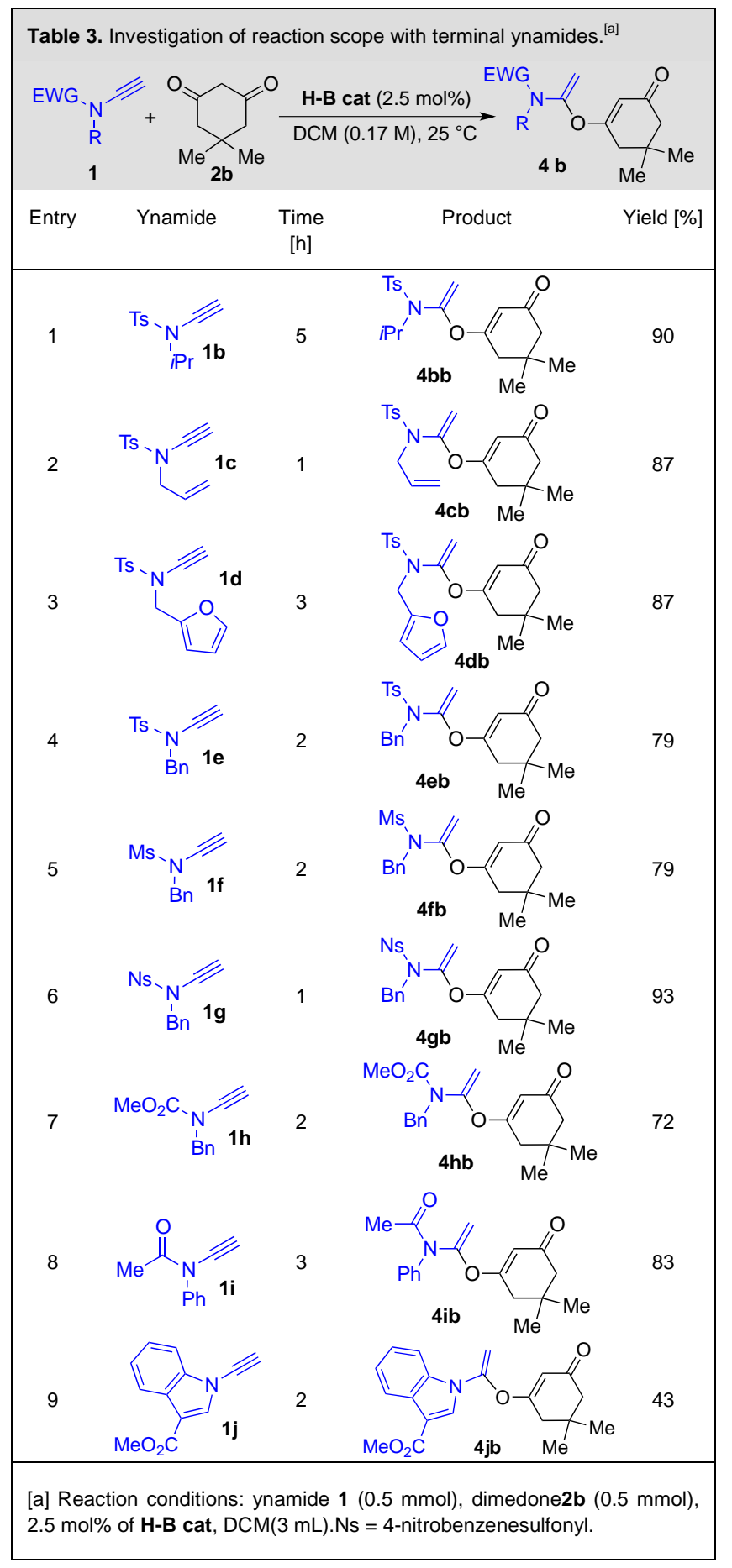

for the Pd-catalyzed addition to 1,3-diones (Table 4). With reoptimized reaction conditions, adducts $7 \mathrm{~b}$ bearing alkyl substituents were obtained with good yields (entries 1-3) and the phenyl-substituted product $\mathbf{7 d b}$ was isolated in a almost quantitative yield (entry 4). With the silylated ynamide $6 e$, no product was detected in the crude mixture. We believe that the 


Table 4. Investigation of reaction scope with internal ynamides. ${ }^{\text {[a] }}$

lack of reactivity might be due to electronic reasons more than to the steric bulk of the TIPS group. Adducts $7 \mathrm{ab}-\mathbf{7 d b}$ were isolated as a mixture of $E$ and $Z$ isomers for which a ratio and the identification were determined by NMR spectroscopies, respectively ${ }^{1} \mathrm{H}$ and NOESY experiments. ${ }^{[19]} \mathrm{No}$ $E / Z$ selectivity was noticed for phenyl-substituted ynamide $6 \mathrm{~d}$

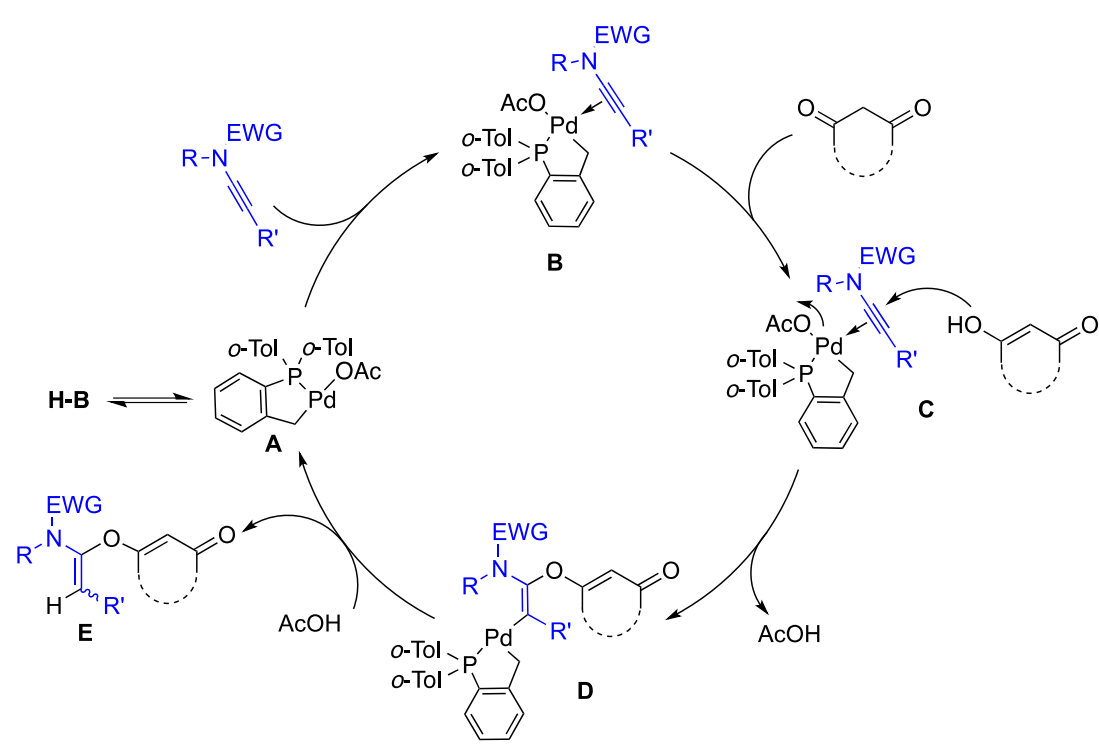

(entry 4), while a little selectivity has been observed with methyl- and Scheme 3. Mechanistic proposal. cyclopropylsubstitutions (entries 1 and 3). Only the ynamide $7 \mathbf{b}$ bearing an-butyl allowed to reach a good $E / Z$ ratio.

A plausible mechanism to explain the catalytic role of the Herrmann-Beller catalyst $\mathbf{H}$-Bis depicted in Scheme 3. $\mathbf{H}-\mathbf{B}$ is in equilibrium with its monomeric form $\mathbf{A}$ which activates the ynamide C-C triple bond and promotes the attack of the 1,3dione enol form. ${ }^{[20]}$ The formation of intermediate $\mathbf{C}$ might be concomitant with an acetic acid release, unless the early departure of the acetate prompts the formation of the more nucleophilic enolate form. This will explain why only 1,3-diones with a $\mathrm{p} K_{\mathrm{a}}$ close to the one of acetic acid can be used in this transformation. Finally, acidolysis of $\mathbf{D}$ releases product $\mathbf{E}$ and catalytic active species $\mathbf{A}$.

In summary, we reported an unprecedented palladiumcatalyzed addition of 1,3-diones to ynamides giving rise to $\alpha$ alkoxy-substituted enamides which, to the best of our knowledge, hadnot been described so far. ${ }^{[21]}$ This transformation was found to be compatible with acidic 1,3diones (pka $\leq 5$ ) and most of the ynamides we have been tested. In a general manner, reactions proceeded smoothly at room temperature - for internal ynamides a heating at $80^{\circ} \mathrm{C}$ is required - and gave high yields. Further investigations are underway in our laboratories to better apprehend the mechanism and improve both selectivities and yields of the addition with internal ynamide partners. The reactivity and synthetic applications of $\alpha$-alkoxy-substituted enamides arealso studied.

\section{Experimental Section}

General Procedure for the palladium-catalyzed addition of 1,3-diones to ynamides:

A $5 \mathrm{~mL}$ Schlenk flask, under nitrogen, was charged with Hermann-Beller catalyst (H-B) $(11.7 \mathrm{mg}, 0.0125 \mathrm{mmol}, 0.05$ equiv. in palladium), and DCM (2 mL). Then, ynamide $(0.5$ mmol, 1 equiv.), 1,3-diketone derivatives ( $0.5 \mathrm{mmol}, 1$ equiv.) and DCM $(1 \mathrm{~mL})$ were added in turn. The reaction mixture was allowed to stir at $25^{\circ} \mathrm{C}$ for the indicated time (TLC monitoring). In the case of internal ynamides, reactions were performed in DCE at $80^{\circ} \mathrm{C}$ for $5 \mathrm{~h}$. Volatiles were removed under reduced pressure and the crude residue was purified by silica gel flash chromatography using petroleum ether and ethyl acetate (gradient $0-50 \%$ ) as eluent leading the pure product.

\section{Acknowledgements}

This work was supported by the Ministère de l'enseignement supérieur et de la recherche (L.G. Ph.D. grant), CNRS, ECM and AMU.We thank Christophe Chendo and Dr. Valérie Monnierfor mass spectrometry analyses and Dr. Michel Giorgifor X-ray determination (Spectropole, Fédération des SciencesChimiques de Marseille), Florian Corne (BTS trainee) for substrate syntheses. Drs A. Tenaglia and I. de Riggi are gratefully acknowledged for helpful discussions as well as Dr Julie Broggi for useful comments on the manuscript. 


\section{Keywords:1,3-dione $\cdot$ enamine $\bullet$ nucleophilic addition $•$} palladium $\cdot$ ynamide

[1] a) X.-N. Wang,H.-S. Yeom,L.-C. Fang,S. He,Z.-X. Ma,B. L. Kedrowski, R. P. Hsung, Acc. Chem. Res.2014, 47, 560-578; b),K. A. DeKorver, H. Li, A. G. Lohse, R. Hayashi, Z. Lu, Y. Zhang, R. P. Hsung, Chem. Rev. 2010, 110, 5064-5106; c) G. Evano, A. Coste, K. Jouvin, Angew. Chem.2010, 122, 2902-2921; Angew. Chem. Int. Ed. 2010, 49, 2840-2859; d) C. A. Zificsak, J. A. Mulder, R. P. Hsung, C. Rameshkumar, L.-L. Wei, Tetrahedron2001, 57, 7575-7606.

[2] For selected references of intermolecular additions at the $\beta$-position, see: a) A. Fadel, F. Legrand, G. Evano, N. Rabasso, Adv. Synth. Catal. 2011, 353, 263-267; b) A. Sato, H. Yorimitsu, K. Oshima, Bull.Korean, Chem. Soc.2010, 31, 570-576; c) N. Saito, T. Katayama, Y. Sato, Org. Lett.2008, 10, 3829-3832;d) B. Witulski, N. Buschmann, U. Bergsträsser, Tetrahedron2000, 56, 8473-8480.

[3] For "umpolung-type" additions of nucleophiles, see: a) Y. Minko, M. Pasco, H. Chechik, I. Marek, Belstein J. Org. Chem.2013, 9, 526-532; b) Minko, Y.; Pasco, M.; Lercher, L.; Botoshansky, M.; Marek, I. Nature2012,490, 522-526 c) J. P. Das, H. Chechik, I. Marek, Nature Chem.2009, 1, 128-132.

[4] Others nucleophiles can be added $\alpha$-regioselectively, see: a) K. Ohashi, S. Mihara, A. H. Sato, M. Ide, T. Iwasawa, Tetrahedron Lett.2014, 55, 632-635; b) P. Maity, M. R. Klos, U. Kazmaier, Org. Lett.2013, 15, 6246-6249; c) A. H. Sato, Kazuhiro, K. Ohashi, T. Iwasawa, Tetrahedron Lett.2013, 54, 1309-1311; d) S. Naud, J.-C. Cintrat, Synthesis2003, 1391-1397.

[5] S. Kramer, K. Dooleweerdt, A. T. Lindhardt, M. Rottländer, T. Skrydstrup, Org. Lett.2009, 11, 4208-4211.

[6] N. Mézailles, L. Ricard, F. Gagosz, Org. Lett.2005, 7, 4133-4136.

[7] S. Kramer, Y. Odabachian, J. Overgaard, M. Rottländer, F. Gagosz, T. Skrydstrup, Angew. Chem.2011, 123, 5196-5200; Angew. Chem. Int. Ed. 2011, 50, 5090-5094

[8] Y. Yang, L. Wang, J. Zhang, Y. Jin, G. Zhu, Chem. Commun.2014, 50, 2347-2349.

[9] D. L. Smith, W. R. F. Goundry, H. W. Lam, Chem. Commun. 2012, 48, 1505-1507.

[10] a) J. Bigeault, L. Giordano, G. Buono, Angew. Chem.2005, 117, 4831-4835; Angew. Chem. Int. Ed.2005, 44, 4753-4757; b) J. Bigeault, L. Giordano, I. De Riggi, Y. Gimbert, G. Buono, Org. Lett.2007, 9,
3567-3570; c) J. Bigeault, I. De Riggi, Y. Gimbert, L. Giordano, G. Buono, Synlett2008, 1071-1075.

[11] H. Clavier, A. Lepronier, N. Bengobesse-Mintsa, D. Gatineau, H. Pellissier, L. Giordano, A. Tenaglia, G. Buono, Adv. Synth. Catal.2013, 355, 403-408.

[12] a) D.-L. Mo, T. Yuan, C.-H. Ding, L.-X. Dai, X.-L. Hou, J. Org. Chem. 2013, 78, 11470-11476; b) G.-C. Ge, D.-L. Mo, C.-H. Ding, L.-X. Dai, X.-L. Hou, Org. Lett. 2012, 14, 5756-5759.

[13] For a review on transition metal-mediated addition of O-nucleophiles to C-C multiple bonds, see: N. T. Patil, R. D. Kavthe, V. S. Shinde, Tetrahedron2012, 68, 8079-8146.

[14] For a rare example of intermolecular addition of 1,3-dione to an allene, see: C. Lu, X. Lu, Tetrahedron2004, 60, 6575-6579.

[15] For singular examples of intramolecular addition of 1,3-diketone to alkynes, see: H. Imagawa, S. Kotani, M. Nishizawa, Synlett2006, 642644.

[16] Crystallographic data for 1a and 4ab: CCDC 1001427 and 1001428 respectively contain the supplementary crystallographic data for this paper. These data canbe obtained free of charge from The Cambridge Crystallographic Data Centre via www.ccdc.cam.ac.uk/data_request/cif.

[17] A. G. Cook in Enamines, $2^{\text {nd }}$ edition (Ed.: A. G. Cook)), Marcel Dekker Inc., New York, 1988, pp. 1-102.

[18] S. Tu, B. Jiang, J. Zhang, Y. Zhang, R. Jia, C. Li, D. Zhou, L. Cao, Q. Shao, Synlett2007, 480-484 and references therein.

[19] For details, see the supporting information.

[20] A similar intermediate to $\mathbf{D}$ was recently purpose in gold-catalyzed oxidation involving ynamides, see: M. Dos Santos, P. W. Davies, Chem. Commun.2014, 50, 6001-6004.

[21] The only related molecule reported in the literature is a functionalized alkylidenecycloproparene: A. T. McNichols, P. J. Stang, D. M. Addington, B. Halton, Tetrahedron Lett.1994, 35, 437-440.

Received: ((will be filled in by the editorial staff))

Published online: ((will be filled in by the editorial staff)) 
Entry for the Table of Contents (Please choose one layout)

Layout 2:

\section{COMMUNICATION}

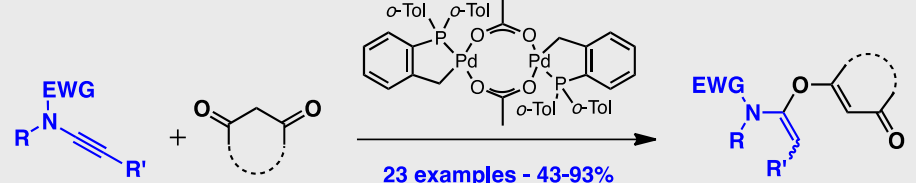

A new metal-catalyzed addition reaction of 1,3-diketones to ynamides providing an access to unprecedented alkoxy-substituted enamides is disclosed herein. After the optimization of the reaction conditions and the catalytic system, the scope investigation revealed a broad applicability to numerous ynamides and cyclic 1,3diones.
Lionel V. Graux, Hervé Clavier, ${ }^{*}$ Gérard Buono

Page No. - Page No.

Palladium-catalyzed addition of 1,3diones to ynamides: an entry to unprecedented alkoxy-substituted enamides 